\title{
Nutritional potentials and in vitro estimation of composite cocoa pod husk-based diets for ruminants
}

\author{
Oluwatosin Bode Omotoso(B)
}

\begin{abstract}
Background: The use of cocoa pod husk in livestock nutrition is being limited because of its fibrous nature and anti-nutrients, which have detrimental effect(s) on the animals. This study was conducted to evaluate the nutritive value and effects of replacing urea-treated ensiled cocoa pod husk meal (urea-treated CPHM) with cassava peel in a complete concentrate diet (CCD) on in vitro digestibility and methane $\left(\mathrm{CH}_{4}\right)$ production.

Methods: Urea-treated CPHM was prepared by soaking the raw milled pod in 5\% urea solution under anaerobic condition for 7 days, and decanted and the filtrates were further ensiled for 28 days, dried, and were replaced with cassava peel meal in CCD at $0,5,7.5,10,12.5$, and $15 \%$ on part basis. Feed samples $(n=3)$ were analyzed for chemical composition, and data generated from in vitro study were subjected to statistical analysis in a completely randomized design experiment.

Results: Results revealed that the treatment significantly reduced the crude fiber, fiber fraction contents, and antinutrients and improved the crude protein content of the pod by $71.84 \%$. Dry matter and crude protein of the diets ranged from $89.34-89.71 \%$ and $10.52-12.84 \%$, respectively. The in vitro dry matter digestibility (IVDMD) increased with increasing levels of urea-treated CPHM in the diets. With increasing levels of urea-treated CPHM, $\mathrm{CH}_{4}$ production relatively reduced as compared to diet E. Metabolizable energy $(5.66 \mathrm{Kcal} / \mathrm{g}$ ) of diet $\mathrm{F}$ was the highest. Therefore, the inclusion of urea-treated CPHM at 15\% in CCDs has the potential for improving digestibility and reducing $\mathrm{CH}_{4}$ production in ruminants.
\end{abstract}

Keywords: Cocoa pod husk, Methane, Ruminant, Urea treatment

\section{Introduction}

Livestock production is undertaken in a multitude of ways across the planet, providing a large variety of goods and services, using different animal species and different sets of resources, in a wide spectrum of agro-ecological and socio-economic conditions (Steinfeld et al., 2006). In recent years, emphases have been shifted to the use of byproducts of agro-industrial origin as low-cost alternative carbohydrate sources for livestock nutrition. Sucharita et al. (1998) concluded that effective utilization of nonconventional feeds should be the major areas of research in the less developed countries due to shortage of conventional feedstuffs, ever-increasing human population and to

Correspondence: obomotoso@futa.edu.ng; tos2bod@yahoo.com

Department of Animal Production and Health, School of Agriculture and

Agricultural Technology, Federal University of Technology, P.M.B. 704, Akure, Nigeria ensure their food security, which is dependent on the better utilization of alternative feed resources. Though ruminant animals can thrive very well on fibrous feeds to keep their rumen healthy, but higher quantities of cellulose, hemicellulose in the cell wall and presence of antinutritional factors usually limit efficient nutrients utilization by the ruminants (Makkar, 1993).

Consequently, cocoa pod husk which is an abundant residue generated on cocoa farmlands has been regarded as a "waste" in Nigeria, except for the negligible amount used in the manufacture of local soap. It has however been reported to contain about $80.00-88.96 \%$ DM, 6.00-9.14\% CP, 24.93-35.74\% CF, and 14.10-21.16\% lignin (Aregheore, 2002; Ozung et al., 2016). To nutritionally upgrade the crop residue for efficient utilization by ruminant animals, urea, a non-protein nitrogen, which
Springer Open

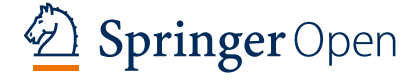

(c) The Author(s). 2019 Open Access This article is distributed under the terms of the Creative Commons Attribution 4.0 International License (http://creativecommons.org/licenses/by/4.0/), which permits unrestricted use, distribution, and reproduction in any medium, provided you give appropriate credit to the original author(s) and the source, provide a link to the Creative Commons license, and indicate if changes were made. 
can be easily converted to ammonia in the rumen, could be effective.

Thus, an in vitro study was conducted to evaluate the nutritive value and effects of incorporating graded levels of urea-treated ensiled cocoa pod husk meal in total mixed rations on digestibility and methane production.

\section{Materials and methods}

\section{Experimental site}

The study was carried out at the Nutrition Laboratory of the Animal Production and Health, Federal University of Technology, Akure (FUTA), located on latitude $7^{\circ} 15^{\prime \prime}$ $\mathrm{N}$ and longitude $5^{\circ} 15^{\prime \prime} \mathrm{E}$ (Ajibade et al., 2014).

\section{Sourcing and processing of feed materials}

Cocoa pod husk was collected at various cocoa farmlands in Ilara-Mokin, Ondo State, sun-dried for 8-12 days, crushed at the FUTA feed mill to 1-mm particle size, and then soaked in the 5\% urea solution under an anaerobic condition for 7 days. Thereafter, decanted and the filtrates were further ensiled for 28 days, dried, and were replaced with cassava peel meals at $0,5,7.5,10$, 12.5 , and $15 \%$ in a complete concentrate diet (Table 1 ). The feed samples $(n=3)$ were analyzed for the chemical composition according to AOAC (2002) method.

\section{In vitro degradability trial}

Two adult male WAD goats of the same age and uniform conformation were selected as donors of rumen inoculum for in vitro studies. The animals were fed for 2 weeks with $40 \%$ concentrate feed and 60\% Panicum maximum at 5\% body weight. Rumen liquor was collected in the morning before feeding through a stomach tube against negative pressure created by a suction pump into the thermo-flask that had been pre-warmed to a temperature of $39^{\circ} \mathrm{C}$. Buffer solution prepared was the McDougall's solution which consist solution (gram/liter) of $9.8 \mathrm{NaHCO}_{3}+2.77$ $\mathrm{Na}_{2} \mathrm{HPO}_{4}+0.57 \mathrm{KCl}+0.47 \mathrm{NaCl}+2.16 \mathrm{MgSO}_{3} .7 \mathrm{H}_{2} \mathrm{O}+$

Table 1 Gross composition of graded inclusion levels of urea-treated CPHM in complete concentrate diets

\begin{tabular}{lllllll}
\hline Diets/level of urea-treated CPHM replacement (\%) \\
\hline Ingredients (\%) & $0(\mathrm{~A})$ & $5(\mathrm{~B})$ & $7.5(\mathrm{C})$ & $10(\mathrm{D})$ & $12.5(\mathrm{E})$ & $15(\mathrm{~F})$ \\
\hline Urea-treated CPHM & 0.00 & 5.00 & 7.50 & 10.00 & 12.50 & 15.00 \\
Cassava peels & 50.00 & 45.00 & 42.50 & 40.00 & 37.50 & 35.00 \\
Brewer dried grain & 27.00 & 27.00 & 27.00 & 27.00 & 27.00 & 27.00 \\
Wheat offal & 5.00 & 5.00 & 5.00 & 5.00 & 5.00 & 5.00 \\
Palm kernel cake & 15.00 & 15.00 & 15.00 & 15.00 & 15.00 & 15.00 \\
Bone meal & 1.00 & 1.00 & 1.00 & 1.00 & 1.00 & 1.00 \\
Salt & 1.00 & 1.00 & 1.00 & 1.00 & 1.00 & 1.00 \\
Premix & 1.00 & 1.00 & 1.00 & 1.00 & 1.00 & 1.00 \\
Total & 100.00 & 100.00 & 100.00 & 100.00 & 100.00 & 100.00 \\
\hline
\end{tabular}

$16 \mathrm{CaCl}_{2} \cdot 2 \mathrm{H}_{2} \mathrm{O}$ and mixed with rumen liquor at $1: 4(\mathrm{v} / \mathrm{v})$ under continuous flushing with $\mathrm{CO}_{2}$ to minimize changes in microbial populations and to avoid $\mathrm{O}_{2}$ contamination for the incubation. Incubation procedure was carried out using 120-ml calibrated transparent plastic syringes with a fitted silicon tube.

The sample weighing $200 \mathrm{mg}(n=3)$ was carefully dropped into syringes and thereafter $30 \mathrm{ml}$ each of the inoculum containing cheesecloth strained rumen liquor and buffer solution. The syringe was tapped and pushed upward by the piston in order to completely eliminate air in the inoculum. The silicon tube fitted to the syringe was then tightened by a metal clip so as to prevent the escape of gas. Incubation was carried out at $39 \pm 1{ }^{\circ} \mathrm{C}$ and the volume of gas production was measured at $3,6,9,12,15,18$, 21 , and $24 \mathrm{~h}$. At the end of the termination hour, $4 \mathrm{ml}$ of $\mathrm{NaOH}(10 \mathrm{M})$ was introduced to estimate the methane production according to Fievez et al., (2005), metabolizable energy (ME), organic matter digestibility (OMD), and shortchain fatty acids (SCFA) were estimated according to the methods of Menke and Steingass (1988). The average of the volume of gas produced from the blanks was deducted from the volume of gas produced per sample. The following were calculated as $\mathrm{ME}(\mathrm{MJ} / \mathrm{KgDM})=2.20+$ $0.136 \mathrm{GV}+0.057 \mathrm{CP}+0.0029 \mathrm{CF} ; \mathrm{OMD}(\%)=14.88+$ $889 \mathrm{GV}+0.45 \mathrm{CP}+0.651 \mathrm{XA} ; \mathrm{SCFA}=0.0239 \mathrm{~V}-0.0601$. Where GV, CP, CF, and XA are total gas volume, crude protein, crude fiber, and ash, respectively.

\section{Experimental design and statistical analysis}

The experimental layout was completely randomized design and all data obtained were subjected to analysis of variance using SAS (2008), and the significant means were separated using Duncan Multiple Range Test of the same package (Duncan, 1955).

\section{Results \\ Chemical composition (\%) of raw CPHM, urea-treated CPHM, and formulated diets}

Table 2 presents the chemical composition of raw CPHM, urea-treated CPHM, and replacement levels of urea-treated CPHM in the total mixed ration. The value of dry matter did not follow a particular trend. However, the values were not significantly $(p>0.05)$ varied. The highest DM (88.97\%) was recorded for raw CPHM and least $(89.34 \%)$ in treatment A (0\% urea-treated CPHM). The crude protein $(\mathrm{CP})$ value of the urea-treated CPHM increased by $71.84 \%$ over the raw CPHM, and this significantly $(p<0.05)$ influenced the CP contents of the diets. Consequently, the protein contents progressively increased with increased replacement levels of ureatreated CPHM in the complete concentrate diets. The highest CP (12.84\%) was recorded for treatment F (15\% urea-treated $\mathrm{CPHM}$ replacement level). The treatment 
Table 2 Chemical composition of raw, urea-treated ensiled cocoa pod husk and formulated diets

\begin{tabular}{llllllllll}
\hline Diets/level of urea-treated CPHM replacement (\%) & & & & & \\
\hline Parameters (\%) & Raw CPHM & Urea-treated CPHM & 0 & 5 & 7.5 & 10 & $\begin{array}{l}12.5 \\
\text { E }\end{array}$ & $\begin{array}{l}15 \\
\text { F }\end{array}$ \\
\hline Dry matter & 88.97 & 89.87 & A & B & C & D & SEM \\
Crude protein & 8.31 & 14.28 & 89.34 & 89.41 & 89.39 & 89.64 & 89.71 & 89.64 & 0.52 \\
Crude fiber & 33.87 & 23.91 & $10.52^{\mathrm{d}}$ & $10.87^{\mathrm{d}}$ & $11.35^{\mathrm{c}}$ & $12.53^{\mathrm{b}}$ & $12.67^{\mathrm{ab}}$ & $12.84^{\mathrm{a}}$ & 0.26 \\
Ether extract & 4.92 & 3.82 & 17.29 & 17.32 & 17.37 & 17.36 & 17.32 & 17.31 & 1.77 \\
Ash & 6.25 & 6.05 & $2.33^{\mathrm{d}}$ & $2.67^{\mathrm{c}}$ & $3.07^{\mathrm{b}}$ & $3.15^{\mathrm{a}}$ & $3.17^{\mathrm{a}}$ & $3.16^{\mathrm{a}}$ & 0.22 \\
NFE & 35.62 & 41.81 & $5.47^{\mathrm{a}}$ & $5.33^{\mathrm{ab}}$ & $5.19^{\mathrm{b}}$ & $5.11^{\mathrm{b}}$ & $5.02^{\mathrm{c}}$ & $5.01^{\mathrm{c}}$ & 0.38 \\
NDF & 63.23 & 52.64 & $53.73^{\mathrm{a}}$ & $53.22^{\mathrm{ab}}$ & $52.40^{\mathrm{b}}$ & $51.48^{\mathrm{b}}$ & $51.47^{\mathrm{b}}$ & $51.32^{\mathrm{b}}$ & 1.34 \\
ADF & 51.40 & 42.21 & $73.90^{\mathrm{a}}$ & $72.62^{\mathrm{ab}}$ & $71.91^{\mathrm{b}}$ & $70.68^{\mathrm{c}}$ & $70.58^{\mathrm{c}}$ & $69.13^{\mathrm{d}}$ & 0.41 \\
ADL & 24.05 & 19.23 & $51.66^{\mathrm{a}}$ & $49.62^{\mathrm{bc}}$ & $50.83^{\mathrm{ab}}$ & $49.13^{\mathrm{bc}}$ & $49.59^{\mathrm{bc}}$ & $48.42^{\mathrm{c}}$ & 0.33 \\
Calcium & 0.41 & 0.51 & $25.14^{\mathrm{a}}$ & $23.37^{\mathrm{b}}$ & $22.42^{\mathrm{b}}$ & $23.17^{\mathrm{b}}$ & $23.19^{\mathrm{b}}$ & $22.48^{\mathrm{b}}$ & 0.26 \\
Phosphorus & 0.11 & 0.20 & $0.54^{\mathrm{d}}$ & $0.56^{\mathrm{cd}}$ & $0.60^{\mathrm{c}}$ & $0.66^{\mathrm{b}}$ & $0.69^{\mathrm{ab}}$ & $0.71^{\mathrm{a}}$ & 0.02 \\
Alkaloid & 6.50 & 3.45 & $0.26^{\mathrm{d}}$ & $0.28^{\mathrm{cd}}$ & $0.29^{\mathrm{c}}$ & $0.32^{\mathrm{b}}$ & $0.34^{\mathrm{a}}$ & $0.35^{\mathrm{a}}$ & 0.01 \\
Theobromine & 3.89 & 2.05 & $0.80^{\mathrm{a}}$ & $1.49^{\mathrm{b}}$ & $1.75^{\mathrm{c}}$ & $2.00^{\mathrm{d}}$ & $2.39^{\mathrm{e}}$ & $2.81^{\mathrm{f}}$ & 0.16 \\
\hline
\end{tabular}

Means on the same row with different superscript letters are statistically $(p<0.05)$ different

A $0 \%$ replacement levels of urea-treated CPHM, B 5\% replacement levels of urea-treated CPHM, C 7.5\% replacement levels of urea-treated CPHM, D 10\% replacement levels of urea-treated CPHM, E 12.5\% replacement levels of urea-treated CPHM, F 15\% replacement levels of urea-treated CPHM, NFE nitrogen-free extract, NDF neutral detergent fiber, $A D F$ acid detergent fiber, $A D L$ acid detergent lignin $(n=3)$

effect caused the significant reduction in the crude fiber level, as $33.87 \%$ CF (raw CPHM) was reduced to $23.91 \%$ (urea-treated CPHM). Though, no significant reduction was noticed in the CF contents of the diets. The ether extract content values gradually increased across the treatment. Though, values recorded for treatment $\mathrm{E}$ and F were statistically $(p>0.05)$ similar. The highest EE $(4.92 \%)$ and ash content $(6.25 \%)$ values were obtained in raw CPHM, respectively. The value of nitrogen-free extract increased numerically from $35.62 \%$ (raw CPHM) to 41.81\% (urea-treated CPHM).

The neutral detergent fiber and acid detergent fiber contents of raw cocoa pod husk were $63.23 \%$ and $51.40 \%$, respectively, and higher compared to NDF (52.64\%) and ADF (42.21\%) of urea-treated CPHM. Similarly, the value of acid detergent lignin (24.05\%) content of raw CPHM was the highest. The CPHM calcium and phosphorus concentrations varied positively with the treatment effect and significantly improved the $\mathrm{Ca}$ and $\mathrm{P}$ contents of the diets. The alkaloid and theobromine concentration of the pod drastically reduced, though the concentration increased with increased levels of urea-treated CPHM in the diets.

Table 3 presents the in vitro gas production of raw and replacement levels of cassava peels with urea-treated cocoa pod husk meal diets. The result showed that gas volume produced at different incubation time differed significantly $(p<0.05)$. The volume of gas produced increased with increasing incubation time (Fig. 1). The study revealed that raw CPHM produced the least gas volume $(1.67 \mathrm{ml})$ at $3 \mathrm{~h}$ and highest $(3.01 \mathrm{ml})$ at $18 \mathrm{~h}$. However, gas production declined after 18th hour. Diet A ( $0 \%$ replacement level of urea-treated CPHM with cassava peels in the diet) produced the least volume of gas (3.33 $\mathrm{ml}$ ) at $3 \mathrm{~h}$ of incubation time, while diet $\mathrm{F}$ produced the highest volume of gas $(9.69 \mathrm{ml})$ under the same period of incubation. Gas volume production at $3 \mathrm{~h}$ was least in diet A $(3.33 \mathrm{ml})$ and highest in diet F $(9.69 \mathrm{ml})$. Similarly, at 24 $\mathrm{h}$, the highest gas volume $(20.19 \mathrm{ml})$ was obtained in diet $\mathrm{F}$ and least $(10.67 \mathrm{ml})$ in diet $\mathrm{A}$ at 21 and $24 \mathrm{~h}$.

Means on the same row with different superscript letters are statistically $(p<0.05)$ different

$C P H M$ cocoa pod husk meal, $A 0 \%$ replacement levels of urea-treated CPHM, $B$ 5\% replacement levels of ureatreated CPHM, C 7.5\% replacement levels of urea-treated CPHM, D 10\% replacement levels of ureatreated CPHM, E $12.5 \%$ replacement levels of

Table 3 In vitro gas production of raw and replacement levels of urea-treated CPHM diets

\begin{tabular}{lllllllll}
\hline \multicolumn{6}{l}{ Gas volume $(\mathrm{ml})$} \\
\hline Diets & $3 \mathrm{~h}$ & $6 \mathrm{~h}$ & $9 \mathrm{~h}$ & $12 \mathrm{~h}$ & $15 \mathrm{~h}$ & $18 \mathrm{~h}$ & $21 \mathrm{~h}$ & $24 \mathrm{~h}$ \\
\hline Raw & $1.67^{\mathrm{f}}$ & $1.82^{\mathrm{e}}$ & $1.99^{\mathrm{e}}$ & $2.13^{\mathrm{e}}$ & $2.47^{\mathrm{e}}$ & $3.01^{\mathrm{f}}$ & $2.89^{\mathrm{f}}$ & $2.89^{\mathrm{f}}$ \\
CPHM & & & & & & & & \\
A & $3.33^{\mathrm{e}}$ & $4.33^{\mathrm{d}}$ & $6.33^{\mathrm{d}}$ & $6.33^{\mathrm{d}}$ & $8.33^{\mathrm{d}}$ & $10.33^{\mathrm{e}}$ & $10.67^{\mathrm{e}}$ & $10.67^{\mathrm{e}}$ \\
B & $4.67^{\mathrm{d}}$ & $5.67^{\mathrm{c}}$ & $6.67^{\mathrm{d}}$ & $7.33^{\mathrm{d}}$ & $9.67^{\mathrm{c}}$ & $11.67^{\mathrm{d}}$ & $11.93^{\mathrm{d}}$ & $12.33^{\mathrm{d}}$ \\
C & $6.00^{\mathrm{c}}$ & $6.00^{\mathrm{c}}$ & $8.00^{\mathrm{c}}$ & $9.00^{\mathrm{c}}$ & $11.00^{\mathrm{b}}$ & $13.00^{\mathrm{c}}$ & $14.00^{\mathrm{c}}$ & $14.07^{\mathrm{c}}$ \\
D & $8.33^{\mathrm{b}}$ & $9.00^{\mathrm{b}}$ & $11.00^{\mathrm{b}}$ & $13.00^{\mathrm{b}}$ & $16.33^{\mathrm{a}}$ & $14.00^{\mathrm{b}}$ & $17.67^{\mathrm{b}}$ & $17.67^{\mathrm{b}}$ \\
E & $9.67^{\mathrm{a}}$ & $11.67^{\mathrm{a}}$ & $14.33^{\mathrm{a}}$ & $14.33^{\mathrm{a}}$ & $16.33^{\mathrm{a}}$ & $17.67^{\mathrm{a}}$ & $20.00^{\mathrm{a}}$ & $20.03^{\mathrm{a}}$ \\
$\mathrm{F}$ & $9.69^{\mathrm{a}}$ & $11.64^{\mathrm{a}}$ & $14.29^{\mathrm{a}}$ & $14.32^{\mathrm{a}}$ & $16.34^{\mathrm{a}}$ & $17.62^{\mathrm{a}}$ & $20.01^{\mathrm{a}}$ & $20.19^{\mathrm{a}}$ \\
SEM & 0.66 & 0.81 & 1.00 & 1.06 & 1.13 & 1.15 & 1.08 & 0.97 \\
\hline
\end{tabular}




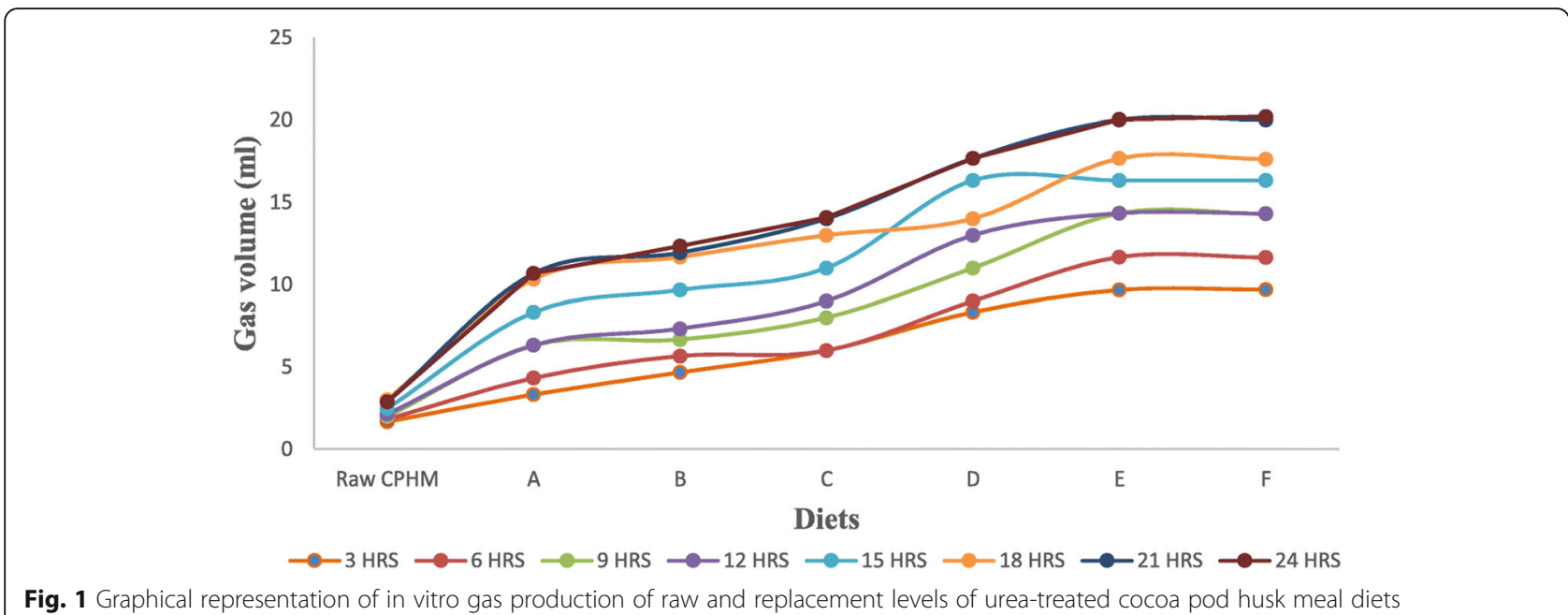

urea-treated CPHM, F 15\% replacement levels of ureatreated CPHM

Presented in Table 4 are the in vitro characteristics of raw and replacement levels of urea-treated CPHM for cassava peels. The result showed a significant $(p<0.05)$ difference for all the parameters assessed with respect to the treatments. It was noted that the least values obtained in all the parameters assessed were for raw CPHM. However, the highest volume of methane gas $(5.00 \mathrm{ml})$ produced was obtained in diets $\mathrm{E}$ and $\mathrm{F}$, while the least was observed in $\operatorname{diets} \mathrm{A}, \mathrm{B}$, and $\mathrm{C}$ $(3.00 \mathrm{ml})$ which were numerically and statistically ( $p$ $>0.05)$ similar. The carbon dioxide $\left(\mathrm{CO}_{2}\right)$ gas produced from the insoluble fraction increased with increased replacement levels of urea-treated CPHM for cassava peels in the diet. Diet F produced the highest volume of $\mathrm{CO}_{2}$ gas $(15.19 \mathrm{ml})$, while diet $\mathrm{A}$ produced the least $(7.67 \mathrm{ml})$. The organic matter digestibility (OMD) obtained ranged from $32.56 \%$ (diet A) to 41.37\% (diet E). The short-chain fatty acid (SCFA) also increased with increased replacement of ureatreated cocoa pod husk meal for cassava peels in the diets; with the highest $(0.42 \mu \mathrm{m})$ value obtained in diet $\mathrm{F}$ and least $(0.19 \mu \mathrm{m})$ obtained in diet A. The metabolizable energy of the diets increased with increased replacement of urea-treated cocoa pod husk meal for cassava peels in the diets. Diets E and F had statistical $(p>0.05)$ similar values but differed numerically. The values of ME obtained ranged from $4.28 \mathrm{Kcal} / \mathrm{g}(\operatorname{diet} \mathrm{A})$ to $5.66 \mathrm{Kcal} / \mathrm{g}$ (diet E). In vitro dry matter disappearance was highest $(80.00 \%)$ in diets $\mathrm{E}$ and $\mathrm{F}$ and least (50.00\%) in diet $\mathrm{A}$.

\section{Discussion}

The $88.97 \%$ DM, $8.31 \% \mathrm{CP}$, and $33.87 \% \mathrm{CF}$ contents obtained for the raw CPHM in this study (Table 2) agreed with the reported values of about 80.0088.96\% DM, 6.00-9.14\% CP, and 24.93-35.74\% CF by Aregheore (2002) and Ozung et al., (2016). The dry matter of the pod before and after treatment (soaking

Table $\mathbf{4}$ In vitro characteristics of raw and replacement levels of urea-treated CPHM diets

\begin{tabular}{|c|c|c|c|c|c|c|}
\hline Diets & Methane (ml) & $\mathrm{CO}_{2}(\mathrm{ml})$ & OMD (\%) & SCFA $(\mu \mathrm{m})$ & ME (Kcal/g) & IVDMD (\%) \\
\hline Raw CPHM & $1.00^{d}$ & $1.89^{e}$ & $25.26^{e}$ & $0.01^{e}$ & $3.16^{f}$ & $42.00^{c}$ \\
\hline A & $3.00^{c}$ & $7.67^{d}$ & $32.56^{d}$ & $0.19^{d}$ & $4.28^{e}$ & $50.00^{\mathrm{bc}}$ \\
\hline B & $3.00^{c}$ & $9.33^{c}$ & $34.15^{c}$ & $0.23^{c}$ & $4.53^{d}$ & $60.06^{b}$ \\
\hline$C$ & $3.00^{c}$ & $11.07^{b}$ & $35.73^{c}$ & $0.28^{b}$ & $4.79^{c}$ & $60.06^{b}$ \\
\hline D & $4.00^{b}$ & $13.67^{\mathrm{ab}}$ & $38.98^{b}$ & $0.36^{\mathrm{a}}$ & $5.29^{b}$ & $70.07^{\mathrm{a}}$ \\
\hline E & $5.00^{\mathrm{a}}$ & $15.03^{a}$ & $41.13^{a}$ & $0.40^{\mathrm{a}}$ & $5.63^{\mathrm{a}}$ & $80.00^{a}$ \\
\hline $\mathrm{F}$ & $5.00^{\mathrm{a}}$ & $15.19^{\mathrm{a}}$ & $41.37^{\mathrm{a}}$ & $0.42^{\mathrm{a}}$ & $5.66^{\mathrm{a}}$ & $80.00^{\mathrm{a}}$ \\
\hline SEM & 0.29 & 2.09 & 0.94 & 0.02 & 0.14 & 3.01 \\
\hline
\end{tabular}

Means on the same row with different superscript letters are significantly $(p<0.05)$ different

$O M D$ organic matter digestibility, $\mathrm{CO}_{2}$ (carbon dioxide) gas production from insoluble fraction, SCFA short-chain fatty acid, ME metabolizable energy, IVDMD in vitro dry matter disappearance, CPHM cocoa pod husk meal, $A$ \% replacement levels of urea-treated CPHM, B 5\% replacement levels of urea-treated CPHM, C 7.5\% replacement levels of urea-treated CPHM, D 10\% replacement levels of urea-treated CPHM, E 12.5\% replacement levels of urea-treated CPHM, $F 15 \%$ replacement levels of urea-treated CPHM 
in 5\% urea solution for 7 days and ensiled for 28 days) and the formulated diets were high; this could be attributed to the dried nature of the pod and cassava peels, culminating in its high lignification. The $\mathrm{CP}$ content of the pod and invariably that of the diets was improved. The CP contents (10.52-12.84\%) of the diets could adequately meet the protein requirement by ruminant animals for growth (NRC, 2007). The reduction in fiber contents could be as a result of the fermentation process during ensiling. The reduction in the alkaloid and theobromine might be traced to decanting after been soaked in urea solution and thus would make the feed more palatable to the animals. The amount of gas produced during fermentation is dependent on the nature, level of fiber, and potency of the rumen liquor used for the incubation. The result showed that gas volume produced at different incubation time differed significantly at $p<0.05$.

The observed increase in the cumulative gas volume from 3 to $21 \mathrm{~h}$ (Table 3 ), and the gradual decline after $21 \mathrm{~h}$ of incubation from diets $\mathrm{A}$ to $\mathrm{F}$ could be associated to the replacement levels of urea-treated CPHM and thus predicted digestibility, fermentation end-product, and microbial protein synthesis of the diets by rumen microbes in the in vitro system. This also implied that digestion would take place within the normal rumen retention time at 21 to $24 \mathrm{~h}$ and could be an indirect measure of dry matter degradability. This trend agreed with the report of Babayemi and Bamikole (2006) when a similar method was used to evaluate the nutritive value of Tephrosia candida DC leaf and its mixtures with Guinea grass for ruminant feeding. From Table 4, methane gas produced was in line with the values reported by Okoruwa and Agbonlahor (2016) when they investigated the gas production characteristics of cocoa pod husk with soursop pulp meals used in replacement for Napier grass in the diet of WAD sheep. Thus, the methane gas volume produced in this study could be traced to the gradual increment in the protein quality of the diets.

The apparently low methane gas volume produced in this study is an indication of the effective utilization of the diets. The gradual increase in the value of OMD and ME reported implied a mutual relationship exists between total methane production and ME with OMD (Babayemi and Bamikole, 2006). The low SCFA reported in this study were due to the lower methane gas production which was evident within the 24-h incubation period. The increased value of IVDMD of urea-treated CPHM-based diets over the raw CPHM could be traced to the effect of soaking in urea solution because great quantities of cell contents were dissolved in the water. Thus, the formulated diets are rich in nutrients, highly digestible, and could meet the nutrient requirements for growth/maintenance by ruminant animals.

\section{Conclusions}

The study established that cocoa pod husk has nutritional potentials in ruminant nutrition and could be nutritionally upgraded by soaking in 5\% urea solution for 7 days, ensiled for 28 days, and incorporated up to $15 \%$ replacement level in the ruminants' diets. However, in vivo study should be carried out to substantiate the in vitro study.

\section{Acknowledgements \\ Sincere appreciation goes to my PhD supervisors-Prof. J. A. Alokan and Dr. A. N. Fajemisin for their mentorship role. \\ Availability of data materials \\ The data that support the findings of this study are available from Omotoso, O. B., but restriction applies to the availability of the data, which were used under license for the current study, and so are not publicly available. Data are however available from the author upon reasonable request and with permission of Omotoso, O. B.}

\section{Author's contributions}

This manuscript is a subset of my doctoral research work. I was responsible to manage all the activities of the experiment and worked in the execution of the trial and involved in the data collection and interpretation to make this manuscript. The author read and approved the

final manuscript.

Author information

ORCID 0000-0002-6181-0467

\section{Funding}

Not applicable

Ethics approval and consent to participate

Not applicable

Consent for publication

Not applicable

\section{Competing interests}

The authors declare that they have no competing interests.

Received: 10 June 2019 Accepted: 9 September 2019

Published online: 17 October 2019

\section{References}

Ajibade FO, Adewumi JR, Oguntuase AM (2014) Design of improved storm water management system for the Federal University of Technology, Akure. Niger J Technol 33(4):470-481

AOAC (2002) Association of Official Analytical Chemists. Official methods of analysis, 17th edn. Published by Association of Official Analytical Chemists, Washington, D.C

Aregheore EM (2002) Chemical evaluation and digestibility of cocoa (Theobroma cacao) by products fed to goats. Trop Anim Health Prod 34:339-348

Babayemi OJ, Bamikole MA (2006) Effect of Tephrosia candida DC leaf and its mixtures with Guinea grass on in vitro fermentation changes as feed for ruminants in Nigeria. Pak J Nutr 5(1):14-18

Duncan DB (1955) Multi rang and multiple F test. Biometrics 11:1-2

Fievez V, Babayemi OJ, Demeyer D (2005) Estimation of direct and indirect gas production in syringes: a tool to estimate short chain fatty acid that requires minimal laboratory facilities. Anim Feed Sci Techno/123-124(1):197-210 
Makkar HPS (1993) Anti-nutritional factors in food for livestock. Br Soc Anim Prod 16:69-85

Menke KH, Steingass $H$ (1988) Estimation of the energetic fed value from chemical analysis and in vitro gas production using rumen fluid. Anim Res Devt 28:7-55

NRC (2007). Nutrient requirements of small ruminants: sheep, goats, cervids, and new world camelids. National Academy Press, 384 p.

Okoruwa MI, Agbonlahor I (2016) Replacement value of cocoa pod husk with soursop pulp meals for Napier grass in the practical diet of West African Dwarf sheep. Eur J Agric For Res 4(5):1-11

Ozung PO, Kennedy OO, Agiang EA (2016) Chemical composition of differently treated forms of cocoa pod husk meal. Asian J Agric Sci 8:5-9

SAS (2008) Statistical Analysis System Institute Inc. SAS/STAT Programme, Carry, NC

Steinfeld, H., T. Wassenaar, T. and Jutzi, S. (2006). Livestock production systems in developing countries: status, drivers, trends. Rev Sci Tech 25 (2): 505-516.

Sucharita S, Makkar HPS, Becker K (1998) Alfalfa saponins and their implications in animal nutrition. J Agric Food Chem 46:131-140

\section{Publisher's Note}

Springer Nature remains neutral with regard to jurisdictional claims in published maps and institutional affiliations.

\section{Submit your manuscript to a SpringerOpen ${ }^{\circ}$ journal and benefit from:}

- Convenient online submission

- Rigorous peer review

- Open access: articles freely available online

- High visibility within the field

- Retaining the copyright to your article

Submit your next manuscript at $\boldsymbol{\nabla}$ springeropen.com 